\title{
Tensions between Western ECCD and the Indigenous African Educational System and What This Means for ECCD Practice
}

\author{
John B. Acharibasam* $\quad$ Dr. Janet McVittie \\ Department of Educational Foundations, University of Saskatchewan, 28 Campus Drive Saskatoon, SK S7N \\ 0X1, Canada
}

\begin{abstract}
Tensions between the current model of Early Childhood Education practiced and the Indigenous or traditional ways of raising children are examined in the context of Ghana and West Africa. Ghana and other West African countries are making efforts to move away from didactic, teacher -directed methods of teaching in early childhood where children are treated as blank slates to be filled with knowledge by the teacher. These efforts are manifested in the multiple early learning theories that have been adopted in curricula to guide practice. However, this paper assesses tensions between the model of early childhood education currently practiced in Ghana (and West Africa more broadly) and Ghanaian Indigenous ways of raising children, which exposes how moving away from the teacher-centered method of teaching is difficult. Drawing on secondary data sources, in the form of a literature review of published articles, government documents, and reports from Non-Governmental Organizations, in this paper we identify that these tensions emerge due to the differences between the current Early Childhood Education program and the Indigenous educational system as well as the marginalization of Indigenous content from the Early Childhood Education program.
\end{abstract}

Keywords: Early childhood education, child-led, teacher-centered, Indigenous, tensions.

DOI: $10.7176 / \mathrm{JEP} / 11-24-13$

Publication date:August $31^{\text {st }} 2020$

\section{Introduction}

Tensions exist between Indigenous or traditional African ways of raising children and the current model of Early Childhood Education (ECE), also referred to as Early Childhood Care and Development (ECCD), practiced in Ghana and West Africa. This issue has received considerable attention from scholars (Nsamenang, 2005; Nsamenang, 2007; Nsamenang \& Tchombe, 2011; Pence \& Nsamenang, 2008). Nsamenang (2007, 2008) observed that the implementation of the ECCD program did not consider Indigenous or traditional African ways of raising children. As a result, the current model of ECE practiced in Africa is based on a Euro-American theory of the universe (Nsamenang, 2007). Sadly, recent times have witnessed an unprecedented increase in the adoption of ECE under Euro-American education models without any consideration of Indigenous West African ways of raising children (Nsamenang \& Tchombe, 2011). Part of the reason is that world organizations hold Western ECE as the best approaches to take and thus African ECCDs are held to the same standards (Ball 2010; Nsamenang, 2008; Pence \& Nsamenang, 2008; Pence \& Marfo, 2008). Therefore, to meet these standards and the expectations of funding agencies, ECCD curricula have been written to model those in the West (Nsamenang, 2008), whilst marginalizing Indigenous content.

Unfortunately, this marginalization has resulted in tensions between ECCD and the Indigenous or traditional African ways of raising children. More worrying is the fact that these tensions have made it difficult to move away from the 'banking model' (teacher-directed) of teaching, despite changed curricula towards more child-led theories of learning. Even when research (see Agbenyega \& Klibthong, 2011; Aizenman \& Warner, 2018; Akyeampong, 2017; Dewey, 1938; Nsamenang, 2007; McCoy \& Wolf, 2018; Woodhouse \& Ndongko, 1993) has shown that the teacher-directed didactic method (what Freire, 1972 termed the banking model) of teaching in ECCD is not effective. The reality on the ground is that teachers find it difficult not to use this didactic instructional method of teaching. Commenting on the ineffectiveness of this instructional model, Woodhouse and Ndongko (1993) concluded that the didactic method of teaching that requires no questioning on the part of students, but only their regurgitation of texts, is not effective in helping students learn. The scholars further noted that this method of teaching does not encourage dialogue and critical thinking in the classroom. This is even worse when teachers employ corporal punishments and intimidation in forcing children to learn, as observed in Ghana (see Aizenman \& Warner, 2018). It has been observed that the use of corporal punishments and intimidation rather leads to poor academic performances in children (Aizenman \& Warner, 2018; Bartman, 2002; Straus \& Paschall, 1998).

Assessments of ECCD in Ghana and other West African countries have shown that ECCD is not achieving its objective of preparing children effectively for primary level of education (Aizenman \& Warner, 2018; McCoy et al., 2016; Ministry of Education, 2016, 2018). In Ghana, for example, "Early Grade Reading Assessment (EGRA) results show that in both 2013 and 2015 only $2 \%$ of pupils in Primary 2 could read at grade level, with $50 \%$ of those tested unable to recognise a single word" (Ministry of Education, 2018, p. xvi). Meanwhile, these pupils graduated from Ghana's ECCD program. One of the major reasons given for this was the over-reliance on the 
teacher-directed or banking model of teaching in ECCD (Aizenman \& Warner, 2018; Sofo, Asola \& Ocansey, 2019).

Hence several efforts are being made to move towards child-led or centered methods of teaching and learning in ECCD (Akyeampong, 2017). In Ghana, for example, Akyeampong (2017) shows how "teacher education program structure and curriculum have been modified to incorporate practicum and learner-centered pedagogy" (p. 195). This is because child-led methods of teaching "are characterized by open and free environments with a generally permissive relationship between the teacher and the children and among the children themselves" (Weikart, 1971, p. 11). This approach promotes dialogue in the classroom and encourages children to think independently as well as critically. Importantly, "content revolves around things of interest or helpful to the child" (Weikart, 1971, p. 11). In addition, Weikart (1971) noted that "Child-Centered curricula is an open classroom with children free to express their individual interests and help create their own environment" (p. 12). Fung (2015) concluded that children are born with certain inherent abilities and it is the responsibility of the teacher, parents, and the community at large to help identify and expand on these abilities. Based on this, Weikart (1971) suggested that curriculum should be developed by the teacher based on "her [sic] own intuitive understanding of child development on the one hand and her observation of the needs of her children on the other" (p. 12). Under childled methods of teaching, play is seen as an important ingredient to learning (Fung, 2015; Weikart, 1971). Tzuo (2007) opined that a child-led or child-centered "curriculum focuses more on the importance of children's individual interests and their freedom to create their own learning through choosing from various classroom activities" (p. 33). Based on the features listed, it can be argued that Hewett's (2001) explanation of the Reggio Emilia approach is consistent with the foundations of child-led teaching approaches. Hewett assessed the approach from the perspective of the child and the teacher. According to the scholar, under the Reggio approach, the child is seen as having rights, is an active constructor of knowledge, a researcher, and a social being. The teacher on the other hand is seen as a collaborator and co-learner, a guide and facilitator, a researcher, and a reflective practitioner (Hewett, 2001).

Having recognized this, Ghana's kindergarten curriculum, for instance, encourages teachers to allow children to choose their own topics to learn, at their own pace, and to use play and other creative learning and teaching approaches rather than the banking model (Abdulai, 2017; Ministry of Education, 2006, 2019). Additionally, teachers are encouraged to identify informal experiences that children enter kindergarten with and to expand on them (Ministry of Education, 2006). The expectation is that this approach will allow teachers to understand children much better and develop alternative teaching methods to suit them. Child-led methods afford children opportunities to respond, question, and even critique teaching (Akyeampong, 2017). Coupled with this, several early learning theories that are child-led have been adopted to guide ECE practice. Some of these include Piaget's (1936) theory of cognitive development, Dewey's (1938) experiential learning theory, Ecological Systems theory (Bronfenbrenner, 1979), the Reggio Emilia approach, the Montessori approach, and Vygotsky's (1978) sociocultural theory of cognitive development. Yet the reality on the ground shows that it is difficult to move away from the banking model of teaching (Akyeampong, 2017; Aizenman \& Warner, 2018). Partly, this is because of the tensions that exist between ECCD and Indigenous ways of raising children. These tensions can be attributed to the marginalization of Indigenous content from the current ECE, and the fact that Indigenous ways of raising children are different from what is currently advocated under ECCD or ECE. Changes towards child-led teaching methods are therefore not congruent with the local culture.

Thus far, other scholars (Abdulai, 2016; Agbenyega \& Klibthong, 2011; Akyeampong, 2017; Asare \& Nti, 2014; Kabay, Wolf, \& Yoshikawa, 2017) have examined teachers' pedagogical practices in ECE and have pointed out a continuous use of teacher-centered approaches in Ghana. However, none of these studies examined the problem in the context of tensions between ECE and traditional African ways of raising children. This paper, therefore, fills this gap by presenting a different perspective (traditional/ Indigenous Ghanaian or West African perspective) to view the problem. That is: from the Indigenous or traditional African ways of raising children. According to Calderon (2014) when educational concepts are viewed from an Indigenous viewpoint, the problems associated with the one-sided Western educational epistemology become more visible. The motivation for this paper is that the move to adopt everything western is very difficult to achieve in a country where the culture is different. This becomes especially apparent with the observation that, upon starting formal school, students do not completely abandon their culture in favour of western culture, but instead tend to seek ways of blending the two belief systems (Jegede, 1994; Fakudze \& Rollnick, 2008).

The paper is divided into different sections with each tackling a particular issue. It began with presenting the context, justifying the relevance of the paper whilst also providing a background. Next, the paper presents the history of ECCD in Ghana and West Africa. The subsequent sections touch on the differences between the traditional African educational system and the current ECCD and proceed to address the tensions between traditional African ways of raising children, contrasted with theories of ECE. Additional reasons are also given to show that, besides these tensions, other factors make it difficult for teachers to move towards child-led teaching approaches. The last sections are the discussion which includes recommendations on the way forward. 


\subsection{Context}

In 2008, United Nations Educational, Scientific and Cultural Organization hosted a group of ECE researchers from various parts of the world to discuss ECE for education for sustainable development (ESD). The editors of the UNESCO report, Samuelson and Kaga (2008), made four points about ECE and ESD: one is that "the notion of the child embedded in the vision of sustainable development is that as portrayed in the United Nations Convention on the Rights of the Child - the child as a right holder, who is an active participant and has his or her contribution to make to society's present and future, and not an invisible, marginal worthless being. In education for sustainable development, young children's perspectives and meanings are listened to, considered, and shape the content and approaches of learning" (p. 12). Second, "children are to be engaged in intellectual dialogue and actions that make a difference in their worlds" (p. 12). Third, diversity - the unique cultures in which children are born, must be considered, understanding that "[e]arly education should help children acquire an identity firmly grounded in a culture closest to them, while developing a sense of themselves as world citizens. One way to promote this is intercultural education" (p. 12). The fourth principle focuses on ESD, although it applies to ECE more generally as well: "children should learn to think critically" (p. 13).

Recommendations from the UNESCO meeting that are of significance to this paper are 1) that there are differences between rich and poor countries, between the global north and south countries, and that gender and other inequalities all contribute to each educational jurisdiction having unique challenges. Immediately after acknowledging this, 2) the recommendation is to draw on early childhood education pedagogies that include "e.g. theme-based or project-based interdisciplinary approach to learning; child-centered approach; parental and community involvement; emphasis on holistic learning, whereby children learn with mind and body; use of different languages and senses, e.g. verbal, visual, etc., for making sense of the world, expressing and communicating" (p. 15).

Much of the report draws on ECE practices found in Euro-American theories: Reggio Emilia, and the Reggio Emilia program refers to Montessori (experiential learning), Dewey (1938) (place-based, inquiry, structured experiential learning), Bruner (1960, 1971) (constructivist, inquiry, experiential learning), and Vygotsky (1986) (teacher guidance to develop an understanding of structured experiences). Reggio Emilia (Wexler, 2004) draws on all these researchers to theorize their child-centered, inquiry, nature-play-based practices. Wexler noted (p. 13) "[g]iving the child the central position in the curriculum often means challenging the cultural paradigms that prevent educators from being fully engaged in the world of children". She pointed out that Reggio Emilia pedagogists, however, refuse to recommend their methodology to other contexts, noting that teachers should read broadly, and should know their own local customs. However, Wexler's takeaway was “[ $\mathrm{t}]$ he teachers at Reggio Emilia create a world where respecting, listening, and collaborating with young children are welcomed and encouraged" (p. 18).

But since Euro-American ideas drive contemporary ECE (see Dahlberg \& Moss, 2005; Nsamenang, 2007; Serpell, 1994), it would seem that these theories are supposed to be taken up in all contexts. As Nsamenang (2008) concluded, world organizations hold Western ECCDs as the standard way to take and African ECCD's are held to the same standards. To meet these standards and the expectations of funding agencies, ECCD curricula have been written to model those in the West. Acting on the UNESCO recommendations, Ghana and other West African countries have made efforts to change ECCD curricula from teacher-centered towards child-led teaching approaches. These changes seem to be informed by some of these Euro-American theories (see Ministry of Education, 2006, 2019) which are not congruent with Indigenous or traditional ways of raising children. This makes it difficult for teachers to make the switch. Teachers are part of the local community and some of them, therefore, have been socialized under these traditional norms and values. As a result, curriculum outcomes may sometimes be difficult to achieve, since they conflict with teachers' and society's beliefs.

This is not just an issue in Ghana or West Africa. Stephen (2012) noted in her research in Scottish primary schools that explicit ECE theory varied from the implicit theory that teachers drew on in their daily practices. Teachers attempted to follow the explicit practices recommended in curricula, but the local context and their own implicit beliefs affected the translation from the curricular document to teaching. The current explicit theory in Euro-American ECE is child-centered, which means children are respected, listened to, and collaborated with in their learning. Nonetheless, the way these practices are taken up vary from context to context, depending on local cultures, with often only the statement that curricula are child-centered.

\subsection{History of Early Childhood Education in Ghana}

According to Prochner and Kabiru (2008), the beginning of ECE (also known as ECCD) in Africa can be traced back to the colonial era. The scholars noted that ECE was in the form of infant schools, kindergartens, and nurseries which mainly instilled Western ideas concerning race, childhood, and religion. The main purpose of these schools was to civilize the African child to adapt to European ways. Consequently, civilization was achieved through the acquisition of Western knowledge which led to the marginalization of local culture (Prochner \& Kabiru, 2008). Due to limited resources, ECE did not receive much attention from West African governments after independence. 
Nonetheless, the launching of the "World Declaration on Education for All" in the 1990s led to the emergence of the current model of ECCD in West Africa (Aidoo, 2008; Ajayi, 2008). ECCD gained more momentum with the introduction of the 2000 Millennium Development Goals and the launching of the Education for All Monitoring Report in Dakar Senegal (Garcia, Pence, \& Evans, 2008). The main aim was to expand and improve ECCD, especially among disadvantaged children. In particular, ECCD was based on the idea that the scope of ECE lies beyond the confines of schooling since young children have multiple needs (United Nations Educational, Scientific and Cultural Organization [UNESCO], 2006).

Garcia et al. (2008) argued that several factors accounted for the adoption of ECCD programs in West Africa. Some of the commonly cited factors include the hope that: early learning experiences would help children transition into primary schools, programs would fill the gap that urbanization created for families by reducing the role of the extended family as caregivers, programs would provide care for the children of the growing number of working mothers and, programs would provide care for the rising number of orphans due to Acquired Immunodeficiency Syndrome.

However, one major critique of the current model of ECE is that it has not done much to include African Indigenous knowledges and ways of raising children (Hyde \& Kabiru, 2003; Ng'asike, 2014; Nsamenang, 2007; Nsamenang \& Tchombe, 2011; Pence \& Nsamenang, 2008; Pence \& Shafer, 2006). Nsamenang and Tchombe (2011) for example observed that recent times have witnessed an increase in the promotion of ECE under the Euro-American education models in a manner that suggests ignorance of the Indigenous African educational system.

Just like other West African countries, the origins of ECE in Ghana date back to the colonial era, when day nurseries were created alongside primary school classes (Boakye et al., 2008). However, the scholars noted that these schools were not only few in number but there was no holistic government policy focusing on all development aspects of the child. Hence, Ghana adopted the current holistic Early Childhood Care and Development (ECCD) approach in 2004 to provide a framework for Ministries, Departments and Agencies (MDAs) to contribute to childhood development (Okai \& Amoah, 2016). Another intention of ECCD was to enhance collaboration between MDAs and stakeholders in providing integrated and well-coordinated services for the optimum development of the child (UNESCO's International Bureau of Education, 2006). For instance, the Department of Social Welfare became responsible for registration and maintenance of standards in all crèches and daycare centers for children aged 0-2, while the Ghana Education Service (the agency in charge of education) assumed the role of curriculum development for children aged 3-5 years (Okai \& Amoah, 2016).

Before 2004, indecision about which ministry would be responsible for ECE in the country had prevailed (Aidoo 2008; Boakye et al. 2008). This was streamlined in 2004 because the government of Ghana realized that the scope of ECE lay beyond the confines of schooling since young children have multiple needs (UNESCO, 2006). Boakye et al. (2008) stated that a holistic government policy focusing on all development aspects of the child was therefore necessary. Hence the implementation of policies and programs to support ECCD was crucial for the development of children between zero and eight years of age (Okai \& Amoah, 2016).

As in other West African countries, similar reasons accounted for Ghana's adoption of ECCD among which was the pressure to meet commitments made to the United Nations Convention on the Rights of Children, the African Charter, and the Millennium Development Goals (Aidoo, 2008; Boakye et al, 2008; Morrison, 2012; Ng'asike, 2014). An example was Ghana's commitments, made at the UN General Assembly Special Session on Children in 2002, to adopt and implement a comprehensive early childhood development policy, towards the realization of the global goal of creating a "World Fit for Children" by the end of the decade (Ministry of Women and Children's Affairs, Ghana, 2004). Other major events that enhanced the adoption and expansion of ECCD in Ghana were the launching of the World Declaration on Education for All in the 1990s and the Education for All Monitoring Report in Dakar Senegal (Garcia, Pence, \& Evans, 2008).

Another reason was the desire to reduce poverty and to better the lives of children in Ghana. According to the government of Ghana's policy on ECCD, "ECCD is also seen as a strategy for poverty reduction" (Ministry of Women and Children's Affairs, Ghana, 2004, p. 3). The document goes on to state: "Considering the high levels of poverty in Ghana, and the several attempts being made to reduce it, this policy initiative is considered an opportunity to invest in young children as a means of addressing the problem" (p. 3). The expectation is that "this will, in the long run, result in an improvement in the standard of living of Ghanaians" (Ministry of Women and Children's Affairs, Ghana, 2004, p. 3).

Agbenyega (2008) indicated that Ghana adopted ECCD because of the urgent need: to address inadequate situations for children by providing access to early childhood services, to respond to an internal obligation to ensure the survival, growth, development, and protection of children as endorsed by the 1992 constitution of the Republic of Ghana, to retain enrolment and enhance the transition of children into primary school, for a strategy for poverty reduction, and to streamline fragmented activities of all early childhood service providers.

However, the reality of ECE in Ghana is that the program has been modeled along western conceptions of Early Childhood Education with little Indigenous content (Abdulai, 2016; Donkor, Issaka, \& Asante, 2013; Tackie- 
Ofosu, Mahama, Vandyck, Kumador, \& Toku, 2015), perhaps in the quest to meet international best practice and the demands of funding organizations (see Ball 2010; Nsamenang, 2008; Pence \& Marfo, 2008; Pence \& Nsamenang, 2008). The influence of international and donor organizations on ECCD in Ghana (and more broadly Africa) is not a new issue. Nsamenang (2008), for example, concluded that World organizations hold Western ECCDs as the standard approach to take and African ECCD's are held to the same standards. To meet these standards and the expectations of funding agencies, ECCD curricula have been written to model those in the West. In the case of Ghana, Casely-Hayford, Palmer, Ayamdoo, and Thompson (2007) observed that over "20 multilateral and bilateral donors have been involved in Ghana's education sector since the reforms began in 1987" (p. 7). They went further to state that "the flow of donor funds to education was dependent on Ghana fulfilling certain conditions set forth by the World Bank and IMF" (p. 8). The authors also observed that "the nature of the conditions varied from donor to donor but some conditions are referred to as performance criteria, and the others are called structural benchmarks and prior conditions" (Casely-Hayford et al., 2007, p. 8).

Besides, each of these organizations (World Bank, IMF) has different interests and objectives which may sometimes conflict with the receiving country's educational objectives. Palmer (2005), for example, stated that the World Bank opposed the vocationalisation of the educational curriculum in Ghana contrary to the wishes of the Ghanaian government. Based on this, Ng'asike (2014) concluded that Western ideologies dominate ECCD because programs are driven and funded by the World Bank and other related multinational agencies, which sometimes disregard the uniqueness of each country. All these factors account for the continuous marginalization of Indigenous Knowledge (IK) in ECCD.

Nonetheless, Pence and Marfo (2008) have cautioned that the purposes that have led bilateral and multilateral international agencies to promote and support ECCD services in Africa may also be paving the way for uncritical adoption of program and service delivery models grounded in value systems and knowledge bases that may not be appropriate for the continent.

Regrettably, whilst efforts have been made over the years to expand and improve the quality of ECE, the inclusion of Indigenous content (such as land-based education and the invitation of Elders into classrooms to teach children), has not received much attention from the government. Even where attempts have been made to include Indigenous content in ECE, these have always focused predominantly on Indigenous language alone to the neglect of other dimensions of Indigenous Knowledges (IKs). As Abdulai (2016) pointed out, although Indigenous languages are used as a medium of instruction in ECCD, few Indigenous games are used for instruction at the early childhood level because they are not part of the Ghanaian ECCD curriculum. What has therefore happened is that some of these changes in curricula, particularly the ones focusing on moving teachers away from the teachercentred method of delivering pedagogy towards more child-led methods, are not congruent with the local culture. Thus tensions have arisen making it difficult for teachers to make that change even when they want to.

The above section traced the history of ECE, the reasons for its adoption in West Africa and Ghana as well as its marginalization of Indigenous content. The next section will go into detail on the differences between the two educational systems, the current theorized and official ECE and the Indigenous African, and how the marginalization of Indigenous content has led to tensions, which in turn make it difficult to move away from the didactic banking model (Freire, 1972) of instruction.

\section{Differences between Current ECE and Indigenous African Educational Systems}

The tensions between Indigenous educational system and the current model of ECCD practiced in Ghana and West Africa emerge from the differences between the two systems. To understand these tensions, the two educational systems are compared side by side (see Table 1). The Indigenous or traditional African educational system has received considerable attention from scholars (see Adeyemi \& Adeyinka, 2002; Boakye-Boateng, 2010; Boateng, 1983; Fafunwa, 1991; MacBeath, 2010; McWilliam \& Kwamena-Poh, 1975; Mundy-Castle, 1975; Nsamaneng, 1992, 2005, 2007; Nsamenang \&Tchombe, 2011; Onwauchi, 1972; Taiwo, 1976; Tedla, 1995; Weisner, 1997). One common theme observed in the literature is that, although there is diversity among the different African cultures, similarities have been identified in their educational systems across the board (see Boakye-Boateng, 2010; Boateng, 1983; MacBeath, 2010; McWilliam \& Kwamena-Poh, 1975; Nsamaneng, 2005, 2007; Tedla, 1995). Boateng (1983) for example concluded that "African education, unlike the formal systems introduced by the colonialists, was inseparable from other segments of life" (p. 322). He explained further that "Traditional African education was not only there to be acquired, but it was there to be lived" (p. 322). The table below shows the differences between the current ECE in West Africa and the Indigenous educational system. The term "Indigenous educational system" is used here to refer to traditional African ways of raising children (see Nsamenang, 2005). 
Table 1.1 Differences between a Western Christian Educational system and an Indigenous African Educational system

\begin{tabular}{|c|c|}
\hline Current ECE & Indigenous/ traditional African Educational system \\
\hline $\begin{array}{l}\text { The process of education is synonymous with } \\
\text { schooling because children go away from family, } \\
\text { playmates, or groups to a specialized institution or } \\
\text { school where they get the fundamentals of general } \\
\text { knowledge and skills, and then professional } \\
\text { abilities (Nsamenang, 2005; Onwauchi, 1972) }\end{array}$ & $\begin{array}{l}\text { The processes of education are usually carried out by the } \\
\text { family, peer group, Elders, and the community through } \\
\text { initiation ceremonies, through some forms of } \\
\text { apprenticeship, and through the daily processes of } \\
\text { existence (Dei, 2000; Onwauchi, 1972) }\end{array}$ \\
\hline $\begin{array}{l}\text { Education is organized into terms and classes } \\
\text { (Onwauchi, 1972) }\end{array}$ & $\begin{array}{l}\text { Education is organized into a sequence to fit different } \\
\text { stages of life (Nsamenang, 2005; Onwauchi, 1972) }\end{array}$ \\
\hline $\begin{array}{l}\text { The process of school training is not integrated } \\
\text { with the daily processes of life (Onwauchi, 1972) }\end{array}$ & $\begin{array}{l}\text { Children are educated through the on-going processes of } \\
\text { life in their traditional customs and values (Boateng, 1983; } \\
\text { Onwauchi, 1972) }\end{array}$ \\
\hline lts teaching children (Onwauchi, & $\begin{array}{l}\text { The pedagogy used is informal, hands-on, and by example } \\
\text { (Fafunwa, 1991; MacBeath, 2010; Nsamenang, 2005; } \\
\text { Onwauchi, 1972) }\end{array}$ \\
\hline $\begin{array}{l}\text { Curriculum divides domains of knowledge into } \\
\text { different disciplines such as; environmental } \\
\text { studies, religious studies, physical education, } \\
\text { mathematics among others (Nsamenang, 2005). }\end{array}$ & $\begin{array}{l}\text { Domains of knowledge are not divided into different } \\
\text { disciplines but rather integrated into one curriculum } \\
\text { (Nsamenang, 2005). }\end{array}$ \\
\hline $\begin{array}{l}\text { Grades and values of individual achievement, } \\
\text { personal ambition, and competition are used to } \\
\text { measure intelligence (Nsamenang, 2007). }\end{array}$ & $\begin{array}{l}\text { Social competence of family, cooperation, and sharing is } \\
\text { used to measure the intelligence of a child (Mundy-Castle, } \\
\text { 1975; Weisner, 1997; Nsamenang, 2007).) }\end{array}$ \\
\hline $\begin{array}{l}\text { Guided by a Western epistemological order } \\
\text { (Nsamenang, 2007; Serpell, 1994). }\end{array}$ & $\begin{array}{l}\text { Guided by an Indigenous epistemological order or } \\
\text { Indigenous philosophies (Nsamenang, 2007; Serpell, } \\
\text { 1994). }\end{array}$ \\
\hline $\begin{array}{l}\text { Western knowledge and foreign language are used } \\
\text { in teaching (Nsamenang, 2007). }\end{array}$ & $\begin{array}{l}\text { Mother tongue and Indigenous Knowledge are used in oral } \\
\text { teaching (Adu-Agyem \& Osei-Poku, 2012; Nsamenang, } \\
\text { 2007; Owu-Ewie, 2006). }\end{array}$ \\
\hline $\begin{array}{l}\text { Emphasizes a more democratic and friendlier } \\
\text { student-teacher relationship (Abdulai, 2017; } \\
\text { Arseven, 2014; Dewey, 1938; Edwards, Gandini, } \\
\& \text { Forman, 1993; Lillard, 2017; Ministry of } \\
\text { Education, 2006, 2019). }\end{array}$ & $\begin{array}{l}\text { e authority of the adult (Fafunwa, } \\
\text { aba, 2014; Owuor, 2007). }\end{array}$ \\
\hline $\begin{array}{l}\text { A child is born with certain abilities (Arseven, } \\
\text { 2014; Dewey, 1938; Fung, 2015; Lillard, 2017; } \\
\text { Ministry of Education, 2006, 2019). }\end{array}$ & $\begin{array}{l}\text { A child is a blank slate in need of protection and training } \\
\text { to adulthood (Ndofirepi \& Shumba, 2014). }\end{array}$ \\
\hline $\begin{array}{l}\text { Content including curriculum revolves around } \\
\text { things of interest or helpful to the child (Weikart, } \\
\text { 1971). }\end{array}$ & $\begin{array}{l}\text { The community's interest takes precedence over the } \\
\text { individual and children are raised based on the } \\
\text { community's interest (Ndofirepi \& Shumba, 2014). }\end{array}$ \\
\hline
\end{tabular}

These differences have resulted in tensions particularly in the introduction of child-led theories of teaching that could create more friendly classrooms and give more freedom to children as the section below will show.

\subsection{Tensions Between ECE and Indigenous/Traditional African Educational System}

Tensions exist between ECE and the Indigenous Educational system and these tensions make it difficult to move away from teacher-centered methods towards child-led educational methods in ECE. This has been demonstrated in Table 1 above. The aim of this section is to show that these tensions make it difficult for child-led teaching methods to be adopted.

First, there exists tension on what type of relationship should exist between children and teachers to encourage dialogue in the classroom. ECCD curriculum, particularly in Ghana (see Ministry of Education 2006, 2019), emphasizes a more democratic and friendlier student-teacher relationship. Importantly, most of the theories (Dewey, Montessori, and Reggio Emelia) that Ghana and other West African governments have adopted to guide ECCD practice discourage the use of corporal punishments and intimidation in classrooms. For example, Abdulai (2017) stated in the context of Ghana that ECCD curriculum allows children: to choose what to learn and at their own pace, to acquire different skills, to select their own activities, and to interact socially. The problem, however, is that most Ghanaian and West African cultures are hierarchical, valuing discipline and the authority of the adult (a person older than the child). In fact, Fafunwa (1991) concluded that one major goal of the African educational 
system is inculcating in children respect for elders and those in a position of authority. Within some cultures, it is even disrespectful for a child to look an elderly person straight in the eyes when communicating or to use the left hand to receive a gift or to give something to someone older (Creider, 1977; Ntuli, 2012; Wieschhoff, 1938). AduGyamfi (2014) observed that "Ghanaian culture stresses reverence and deference to elders and authority at all times, as causing an adult to 'lose face' (embarrassed) is considered disrespectful" (p. 7). The scholar went further to state that children "cannot challenge or disagree with decisions made by adults which they are not in favour of" (p. 7). Children who have been socialized in these cultures may, therefore, find it difficult to express their views in class (especially views that are different from their teachers) irrespective of the early learning theory adopted. Owuor (2007) observed a similar trend in the Kenyan context. Besides, teachers who have been socialized in this type of culture may not take divergent views kindly and interpret them as being disrespectful. Therefore, some of these theories conflict with Indigenous cultures and learning systems.

Similarly, due to the huge emphasis on discipline, parents and society may pressure teachers to employ corporal punishments and intimidation (see Aizenman \& Warner, 2018; Kabay, Wolf, \& Yoshikawa, 2017). According to Ndofirepi and Shumba (2014), Indigenous African communities recognize that "childhood is a shaky state where the young must be sheltered and granted support in conformity with the cultural ends" (p. 237) because childhood is seen as the beginning where a child learns to become a person (Ndofirepi \& Shumba, 2014). The scholars further observed that personhood is not automatically granted at birth but rather it is attained. To attain this, the child must go through a socialization process and the child can even fail to become a person (Ndofirepi \& Shumba, 2014). As a result, all efforts must be made to socialize the child in the cultural norms and values of society even if it demands corporal punishments. Based on this, Ndofirepi and Shumba (2014) concluded that "The image of the child is one of strict discipline and parental constraint and traditional Africans are convinced that if left to their own devices, children would turn out badly" (p. 238). Hence, some child-friendly theories (sometimes referred to as child-centered, activity- and play-based approaches by Kabay et al., 2017) emphasized by ECCD promote teaching practices that are seen not to be disciplined enough. Ogbujah (2013) noted in the context of Nigeria that education should not only train the child cognitively but also instill discipline and moral rectitude in children. The scholar went further to state that Dewey's ideas on education do not address instilling discipline and moral rectitude in children. Thus, Dewey's ideas, in the Nigerian context, leave teachers confused as to which teaching method to adopt. These differences in what some cultures demand and what curricula demand from teachers create tensions. Ultimately, the tensions make it difficult for teachers to adopt child-led theories of education.

Second, another source of tension between ECE and the Indigenous West African educational system (and ways of raising children) that makes it difficult to adopt child-led theories is how children are perceived (also referred to as the image of the child by Hewett, 2001). Child-led theories in which ECE curricula promote the perception of children as being born with certain abilities and the teacher's, parents', or community's responsibility is to identify and expand on these abilities (Hewett, 2001). In the Reggio Emilia approach for instance a child is seen as a curious social creature full of intelligence right from birth (Arseven, 2014; Hewett, 2001). Based on this, Fung (2015) concluded that children are born with certain inherent abilities and it is the responsibility of the teacher, parents, and the community at large to help identify and expand on these abilities. Another premise of the childled method of teaching is that the curriculum should revolve around children's interests. As Weikart (1971) concluded, "content revolves around things of interest or helpful to the child" (p. 11). Meanwhile, Ndofirepi and Shumba (2014) observed that some Indigenous African communities (traditional paternalistic ones) treat "the child as a blank slate in need of protection and training for adulthood" (p. 236). Childhood is viewed "as the time to learn, to build a character, and to acquire the social and technical skills necessary to perform the future roles of adulthood" (Rwezaura, 1998, p. 255). In contributing to this, Boakye-Boateng (2010) stated that Indigenous African communities consider children as "biologically vulnerable beings in need of protection and nurturing" ( $p$. 108). Through socialization, they are "to be developed, stretched and educated into their future adult roles" (Ndofirepi \& Shumba, 2014, p. 235). These roles are designed based on societal norms and responsibilities and not on an individual child's interest (Ndofirepi \& Shumba, 2014). Hence, the socialization process is carried out by the entire community. In Indigenous African communities, a child is everybody's child (Hansungule 2005, cited in Ndofirepil \& Shumba, 2014). Furthermore, children are considered as being part of the community and the community's interest takes precedence over the individual. As Ndofirepil \& Shumba (2014) concluded "Traditional Africans endorse the view that the community is more important than the individual and it takes precedence over the individual" (p. 235), revealing that it is not just the child who must moderate personal goals for the community's goals. Hence teaching and learning in Indigenous communities cannot revolve around things of interest or helpful to the child but rather the community as a whole. In fact, "The community demands that the child forsakes individual good in order to submit to the collective interests" (Ndofirepi \& Shumba, 2014, p. 235). Hence these differences in perceptions create tensions that ultimately make a switch over to child-led theories difficult. This is because teachers who have been socialized under this system may continue to view the child as an empty slate to be filled with knowledge. Again, teachers may find it difficult to base teachings on individual 
children's interests rather than the common good of the community.

Closely related to the above point is how intelligence is perceived. In Indigenous or traditional African communities, age is regarded as a determiner of wisdom or intelligence. Unlike child-led theories which suggest that right from birth a child has certain abilities, traditional African communities believe that intelligence or wisdom is not present at birth (Ndofirepi \& Shumba, 2014). Rather the older one grows the wiser he or she becomes. It is believed that "because adults have had sufficient experience of life and are ethically complete due to their own earlier training while children's cognitive faculty for deliberation is not developed, children are not capable of choice" (Ndofirepi \& Shumba, 2014, p. 238). Similarly, Muyila (2006, cited in Ndofirepi \& Shumba, 2014) observed that advancing in age therefore means continual improvement and accessibility to more knowledge and wisdom.

In Ghana for example many traditional groups hold the view that an elder is always right and it is disrespectful to criticize, argue with, or challenge him or her, especially in public (Adu-Gyamfi, 2014). Salm and Falola (2002 cited in Adu-Gyamfi, 2014) observed that children's reverence for elders at all times is influenced by a belief in ancestral worship. Adu-Gyamfi wrote "It is believed that ancestors can either punish or reward the living" (AduGyamfi, 2014, p. 8), adding "elders are the conduit of communication with the ancestors" (p. 8). As a result of this "respect and reverence for elders could engender rewards for a meaningful life" (p. 8). Given this perception, it will be hard for children who have been socialized under this system to criticize, argue with, and challenge a teacher in class even when the teacher is wrong. Besides, children who have been socialized under this system may assume that since the teacher is an elderly person, he or she is wiser and cannot make mistakes.

Third, so far as education takes place in a formal setting, the classroom, there will always be the temptation to use a teacher-centered method in Ghana and West Africa. Owuor (2007) concluded that "the Western-based schooling system recognizes teachers' professionalism as central in facilitating the process of classroom knowledge construction" (p. 28). In this sense, the teacher is held as the epitome of knowledge. However, in Indigenous African communities knowledge is co-owned and neither property nor an object which the teacher possesses (Nsamenang, 2005). "Children were encouraged to observe and learn from their involvement in the life of the family, cultural and economic activities" (Nsamenang, 2005, p. 329). The scholar further stated that this was practical and "done without formal instruction but with encouragement and support from family, peers, and the community" (p. 329). Similarly, Saayman (1991) observed that traditional "African education generally took place by means of observation, imitation, and explanation" (p. 32). As long as the perception of the teacher as the epitome of knowledge exists in Ghana and West Africa, and the belief that knowledge is owned by teachers, and that formal classrooms do not properly cater to the role of peers, family, and the community in educating the child (Nsamenang, 2005), it will be very difficult to move towards child-led theories. The rearing of the child was not the responsibility of only one adult (teacher) but all well-meaning members of the society (Boakye-Boateng, 2010; Kilbride \& Kilbride, 1994; Nsamenang, 2005). Based on this Fafunwa (1991) posited that in a traditional African society the child intuitively jumps, climbs a tree, eats certain fruits, dances, or performs a balancing act because he or she sees members of the community do the same. Under the Indigenous educational setting there were different sources to learn from (peers, family, elders, and the community at large) hence the child did not look up to only one person, the teacher, as the only source of knowledge to have his or her questions answered. The child will always look up to the teacher to choose topics to learn no matter what the curriculum says, especially, when what is taught in class is new to the child.

\subsection{Other Challenges to the Shift to Child-led Teaching}

Besides the tensions with Indigenous ways of raising children, other factors make it difficult for teachers to adopt child-led teaching systems. Among these is the assessment culture in Ghana and West Africa. There is an overreliance on formal assessments in ECE. Although children are not supposed to be formally assessed under ECCD (Asare, 2015; Olaleye, \& Omotayo, 2009), studies indicate the children are formally assessed. In the case of Ghana, Osei-Poku and Gyekye-Ampofo (2017) found that formal assessments were still used by teachers because officers from the Ghana Education Service (the agency in charge of education) insists that formal examinations be conducted. Likewise, Aizenman and Warner (2018) indicated that children were assessed on basic literacy and numeracy when progressing into upper primary classes. The scholars commenting on a government of Ghana assessment of ECCD indicated that ECCD was not effective because most children failed in basic literacy and numeracy tests. The major objective of this assessment is that at least children graduating from pre-school should be knowledgeable in basic literacy and numeracy. Asare (2015) noted the "educational programme quality now is being judged by children's' test scores" (p. 111). Meanwhile, McCoy and Wolf (2018), in their assessment of the quality of ECCD in Ghana, observed there were "no culturally sensitive instruments available for understating process quality" (p. 9).

However, this assessment leads to the question of whether teachers are supposed to be teaching only reading and writing in ECCD? The answer is yes. One of the objectives of ECCD is to prepare children for the primary level of education in West Africa (Garcia, Pence \& Evans, 2008). This goal is based on research that has shown 
that ECCD improves the child's school readiness, ability to learn, self-confidence, and transition to higher levels of primary school (Jaramillo \& Tietjen, 2001). Based on this, there is pressure on teachers to be more academic and results-oriented irrespective of what the curriculum says. Asare (2015) concluded that "Modern Ghanaian society and other societies the world over have placed great expectations on the early years of life" (p. 111). This confirms Bidwell and Watine's (2014 cited in Kabay et al., 2017) assertion that most African cities emphasize mainly the development of children's academic skills in preschools. Parents and the Ghana Education Service expect children who have undergone the ECCD program to be knowledgeable in basic literacy and numeracy (see Aizenman \& Warner, 2018; Asare, 2015). Similar results were found in other West African countries (Ajayi, 2019). Thus, making a step away from academic-focused and teacher-centered teaching has been made difficult, as it creates tension between what the teachers are told they are to teach, and what the parents (the community) expect the goals to be, and what the curriculum (and perhaps the teachers) see as the goals for early learning. Likewise, there is confusion about which early learning theories to pursue in order to achieve these outcomes. Child-led theories draw out children's ability to think and reason and not to only memorize alphabets and numbers.

Furthermore, teachers have too many topics to cover with huge class sizes. This leads them to choose a teaching method that is less hectic and generates quick results for standardized tests, as befit the banking model of education. With this model, the teacher can teach children to memorize and regurgitate text and even employ corporal punishment where necessary to achieve results. As Ndofirepi (2011) concluded, "Didactic teaching is a product-oriented approach, with output being measured in terms of achievement in examinations, and is characterized by the absence of independent thinking and the presence of unquestioned obedience to authority" ( $p$. 246). Child-led theories on the other hand expect the teacher to pay particular attention to each child, to let them choose their own topics, and to learn at their own pace (Abdullai, 2016). For teachers with huge class sizes, many topics to cover, and pressure on them to complete the curriculum, it can be frustratingly difficult to adopt childled methods of teaching. Allowing children to choose their own topics takes the time to negotiate this, and when children learn at their own pace, overall learning might slow down. Having children learning different topics at different rates will be time-consuming for the teacher. Besides classrooms (building size) are too small to provide children with enough space to work independently (Abdulai, 2017).

Another reason child-led learning is not adopted is the non-availability of qualified teachers. The adoption of child-led learning as supported by theories such as Montessori and Reggio Emilia come with higher expectations from teachers. Onu, Obiozor, Agbo, and Chiamaka (2010) concluded that "Teachers are expected to be continually engaged in the process of learning about young children, both through ongoing professional development and through careful observation of the children in their classes" (p. 212). The scholars further noted, "The teachers then reflect together on what they have learned and use such experience as a basis for future activities intended to expand on initiatives of the child" (p. 212). But Ghana and other West African countries do not have the teachers with the skills and training to achieve these expectations (Ajayi, 2008; Asare, 2015; Cobbold \& Boateng, 2015; Olaleye \& Omotayo, 2009). In the case of Ghana, Asare (2015) concluded that "teachers lack the requisite knowledge on the use and practices involved in the impact of performance assessment on their own professional development" (p. 125). Besides, West African governments may not have the necessary funds to help teachers buy teaching materials to truly carry out Montessori or Reggio Emilia.

\section{Discussion}

The paper examined tensions between the traditional African ways of raising children and the current model of ECE practiced. It was observed that these tensions make it difficult for teachers to move towards child-led learning methods even in the face of failure to deliver quality results in early learning. These tensions emerged largely because the theories informing international ECE curricula are not congruent with the local culture. Coupled with the continuous marginalization of Indigenous content in ECE, it is, therefore, difficult to make the switch away from teacher-centered methods of teaching curriculum. Nonetheless, it was observed that, besides these tensions, there are other factors militating against the move towards child-led teaching methods.

The problem with child-led teaching methods is that they fail to recognize that in some Indigenous or traditional West African cultures, it is the community that matters and not the child as an individual. The emphasis is on collective co-existence and interdependence and the individual is seen as part of the group (Khupe, 2014). This is not to say that individuals cannot make their own choices and set their own goals (see Bell, 2002; Gyekye, 1997; Ndofirepi \& Shumba, 2014) but what has to be understood here is that consequences for individual's wrong actions (such as adultery, incest, stealing among others) bring curses to not only the individual but the entire community (see Idang, 2015). This is part of the reasons why the community's cultural values guide an individual's upbringing and actions. As a result, community practices for raising children are different from what child-led teaching methods emphasize. Under Indigenous Ghanaian and West African culture, children interact with peers to play games which prepare them to fit into the culture; children learn from observing their elders with no formal instruction (teacher in front of children with a cane in hand leading discussions); children are expected to behave well, and are chastised by elders if they make poor choices; children cannot challenge elders; children are perceived 
to be born without knowledge, and learn as they are taught by their families, the community, and elders; children are expected to contribute to the community, not be self-centred. These practices are completely different from child-led theories which emphasize friendlier relationships between children and the teacher, centering learning on the interest of the child; children been given the freedom to select what they want to learn. Again, child-led methods of teaching discourage the use of corporal punishment and intimidation in teaching children which may sometimes be employed under Indigenous cultures due to the emphasis on discipline and respect for the elderly. Given these, it will be difficult for teachers who have been socialized under this system to adopt child-led methods of teaching. Likewise, children who have been socialized under this cultural training may find it difficult to criticize or challenge the teacher. Equally, parents and community at large may even put pressure teachers to employ corporal punishment should they realize they (teachers) are not disciplining children enough.

Another problem that this paper identified in the adoption of child-led theories was in curricula intentions. Currently, curricula draw on ECE theories from Reggio Emilia, Dewey, Montessori, Vygotsky, and inquiryresearch. By that, the curriculum outlines that children be allowed to find interesting topics to explore at their own pace versus actual ministry expectations (children are put into ECCD programs for a variety of reasons, prominent among which include children be readied for primary level education). But it was noted that this readiness is not about developing confidence and social skills, but rather is about getting a jump on literacy and numeracy. Tests have revealed that the ECCD programs are not meeting these literacy and numeracy goals (see Ministry of Education, 2018), and so teachers are expected to do more drill and practice. However, this leads to the question of what it means to ready children for school. Broadly, this paper is of the view that children are ready for school because they are happy and confident in large social groups. They start in small comfortable groups (under ECE) and gradually the group size grows as they progress to upper classes. Hence ECE should not be about the extending of formal learning to children under ECE. As a result of these differences, there exist a conflict between the goals of the ECCD curricula and the ministry tests that lead to a push for children to be literate and numerate.

We also identified more practical issues that impeded the adoption of child-led teaching approaches. Some of these included: limited resources, class sizes (in terms of a large number of pupils and small classroom blocks), and the lack of qualified teachers. Under child-led teaching methods, teachers play a very instrumental role. According to Onu et al. (2010), "Teachers are expected to be continually engaged in the process of learning about young children, both through ongoing professional development and through careful observation of the children in their classes" (p. 212), after which "The teachers then reflect together on what they have learned and use such experience as a basis for future activities intended to expand on initiatives of the child" (Onu et al., 2010, p. 212). Similarly, Hewett (2001) observed that the teacher should be: a collaborator and co-learner, a guide and facilitator, a researcher, and a reflective practitioner. In fact, Weikart (1971) suggested that curriculum should be developed by the teacher based on "her [sic] own intuitive understanding of child development on the one hand and her observation of the needs of her children on the other" (p. 12). However, it was observed that ECCD teachers in Ghana and other West African do not possess the skills and training to achieve these expectations (see Ajayi, 2008; Asare, 2015; Cobbold \& Boateng, 2015; Olaleye \& Omotayo, 2009). Again, for child-led teaching approaches to work, children need enough space to work independently. Unfortunately, as reported by Abdulai (2017), classrooms are too small to permit independent work without constant interruption from peers.

The paper examined some of the reasons impeding Ghana's (and broadly West Africa's) movement towards child-led/ centered methods of teaching in ECE. Research was demonstrated to show that the theories informing child-led teaching methods do not conform to the Indigenous/ traditional African ways of raising children. Based on this, tensions have emerged which are preventing teachers from moving away from teacher-centered methods of teaching even in the face of failure to achieve quality learning. This paper also identified that, besides these tensions, other practical issues exist which make the adoption of child-led teaching methods difficult. In line with Aoki's (1993) suggestion that curriculum-as-lived experience is not found only in the child, or teacher, or subject, we suggest in the context of Ghana (and broadly West Africa) that the issue should not be about child-centered versus teacher-centered alone but rather should be de-centered. In a de-centred curriculum, there is interplay of the teacher, child, and culture/ society which leads to the development of a teaching approach to guide practice. Furthermore, efforts must be made to find a common ground between the ECE program as a whole and the traditional ways of raising children. This can start with a genuine effort to Indigenize ECE in the region. Again, efforts must be taken to solve some of the practical issues we outlined in this paper if child-led teaching methods are to be effective.

\section{Conclusion- How Indigenous and Western Approaches can be Integrated}

There are different ways by which Indigenous content can be integrated into classroom education (see Kimmerer, 2002; Ohmagari1 \& Berkes, 1997; Turner, Ignace \& Ignace, 2000). However, to help improve the situation in Ghana and West Africa, we recommend a re-examination of not only the ECCD program but also teacher training programs. Changes in only ECCD curricula to include Indigenous content may not be the answer. As research (see Dei \& Simmons, 2011) has already shown in Ghana, most teachers are not trained in IKs and therefore do not 
know how to teach Indigenous content. Hence, if even curricula are changed to include Indigenous content and teachers lack the necessary training in Indigenous knowledges, the situation may not change. Efforts must, therefore, be made in Ghana and West Africa to re-examine teacher education as well. This can be done by adopting an overarching guiding principle or framework (like the two-eyed seeing approach or land based education principles) to guide all levels of education, including teacher training programs. From curriculum design to the final teaching of curriculum in the classroom, this overarching framework should guide practice.

However, for this to be achieved, there has to be equal respect and value for both Indigenous content and Western approaches in schools. Unfortunately, this cannot be found yet in the context of Ghana and West Africa (see Onwauchi, 1972; Semali \& Kincheloe, 1999; Taiwo, 1976)). Turner et al. (2000) argued that in order for Indigenous Knowledges (IK) to be incorporated into any program, the complete context of IK, including its philosophical bases, must be recognized and respected. Similarly, Simpson (2002) asserted that it must be recognized that "Indigenous Knowledge and Indigenous education philosophies on their own terms are valid ways of teaching and learning, equal to their Western counterparts" (p. 17). A study by Shizha (2007) showed that besides institutional challenges, the negative attitude of teachers towards IK (seeing IK as less valuable to Western knowledge) was a major challenge to integrating Indigenous content into education in Zimbabwe. Perhaps if teachers' training programs were based on a two-eyed seeing approach, the negative attitude may have been solved. Teachers would have been trained to appreciate the best from both worlds and to understand that Western approaches and Indigenous knowledges are equally important (see Hatcher \& Bartlett, 2009).

As a result, scholars cautioned that care must be taken when putting two knowledge systems together, because one of them may be dominated (Kim et al., 2017). Kim and Dionne (2014) suggested that it is essential to create a venue for true experts to share their knowledge directly with learners. The scholars propose the invitation of Elders who are the true holders of IK into classrooms to teach children. Likewise, Dei (2000) suggests "hiring Indigenous and racial minority scholars to join teaching faculties and to integrate Indigenous knowledges into the curriculum, as well as into the instructional and pedagogic practices of educators and learners" (p.119). Kimmerer (2002) recommended that either IEK be included as a new topic on its own or integrated as examples into the teaching material of existing topics. Additionally, Kimmerer (2002) suggested that Elders be invited into classrooms as a resource person and guest speakers. Jegede (1994) proposed in the context of science education in Africa that familiar materials and processes be used to integrate Indigenous content into the teaching of Western science. The scholar concluded that "Science education and learning must begin from where the child is, even if it means beginning with the examination of the traditional belief system" (p. 8).

In the context of Ghana (and broadly West Africa), these same approaches can be adopted to integrate Indigenous and Western approaches in ECCD.

We recommend that space should be created in the curriculum for Indigenous content and the invitation of Elders into classrooms to teach children Indigenous content. Apparently, this is not limited to Ghana and West Africa alone as Owuor (2007) makes a similar recommendation in the context of Kenya that curriculum should be reconstructed to make room for Indigenous content. This can be done by either including Indigenous knowledge in the curriculum as a new topic on its own or integrate it as examples into teaching material of existing topics (Kimmerer, 2002). Whichever approach a country chooses will depend on the context. But the overarching guiding principle should be that both Western approaches and IK are equal (Hatcher \& Bartlett, 2009).

This will also mean that a more practical approach to teaching is adopted. Ohmagari and Berkes (1997) pointed out that IK is not taught by formal education in the abstract and the best way is learning by doing. Based on this, we recommend a more experiential approach of taking pupils outdoors to engage in learning about IK. Teachers should also be encouraged to base learning on materials and belief systems that are familiar to children in ECCD.

The value of child-led teaching approaches to early learning cannot be underestimated, and we understand the reasons behind Ghana's (and broadly West Africa's) efforts to adopt child-led approaches. Nonetheless, we caution that these be re-examined thoroughly vis-à-vis traditional or Indigenous ways of raising children. Because as we stated above to successfully adopt child-led approaches will mean to do away with certain core cultural values (such as the child belonging to the entire community and the community's interests supersedes that of the individual) and are we saying these cultural values are no longer important? As Nsamaneng (2007) posed the question on the current model of ECCD practiced "should African societies be required to diverge from their investment in children as social capital of their communities to the individualism implicit in much of the Westernorientated ECCE research and policies?" (p. 5). The scholar goes further to indicate that there are important values (such as sibling caretaking) in traditional African ways of raising children that cannot be excluded from ECCD because doing so would rather disempower African peoples. Nsamaneng (2007) stated that during the AIDS pandemic in sub-Saharan Africa it was not donor money alone that helped reduce the AIDS deaths rate but sibling caretaking. Coupled with help from the extended family and the community at large. According to him, this is "a role that is positively valued in African culture and that primed children into responsible family service from an early age and facilitated their transition into adult roles with the death of parents and caregivers" (p.5). This cultural 
value among others emerged from the traditional African ways of raising children. Hence we conclude that childled teaching approaches should consider important cultural values such as these.

\section{References}

Abdulai, A. (2016). Pedagogy of indigenous play: The case of Ghana's early childhood education. International Journal of Research and Review in Education, (3), 28-34.

Abdulai, A. (2017). Activities at early childhood centers in Ghana: Observations of early childhood teachertrainees. Asian Journal of Education and Training, 3(1), 74-81. https://doi.org/10.20448/journal.522.2017.31.74.81.

Adu-Gyamfi, J. (2014). Childhood construction and its implications for children's participation in Ghana. African Journal of Social Sciences, 4(2), 1-11. . http://dx.doi.org/10.15640/jehd.v5n3a17.

Adeyemi, M. B., \& Adeyinka, A. A. (2002). Some key issues in African traditional education. McGill Journal of Education, 37, 223-240.

Adu-Agyem, J., \& Osei-Poku, P. (2012). Quality education in Ghana: The way forward. International Journal of Innovative Research \& Development, 1(9), 164-177.

Agbenyega, J.S., \& Klibthong, S. (2011). Early childhood inclusion: A postcolonial analysis of pre-service teachers' professional development and pedagogy in Ghana. Contemporary Issues in Early Childhood, 12(4), 403-414. https://doi.org/10.2304/ciec.2011.12.4.403.

Agbenyega, J. (2008). Development of early years policy and practice in Ghana: Can outcomes be improved for marginalized children? Contemporary Issues in Early Childhood, 9(4). https://doi.org/10.2304/ciec.2008.9.4.400

Aidoo, A. A. (2008). Positioning ECD nationally: Trends in selected African countries. In M. Garcia, A. Pence \& J.

L. Evans (Eds.). Africa's Future, Africa's Challenge Early Childhood Care and Development in Sub-Saharan Africa (pp.29-48). The International Bank for Reconstruction and Development / The World Bank. Washington DC.

Ajayi, H. O. (2019). Analysis of the pre-primary school children assessment procedure in Nigeria. Asia-Pacific Journal of Research in Early Childhood Education, 13(1), 69-83. http://dx.doi.org/10.17206/apjrece.2019.13.1.69.

Ajayi, H.O. (2008). Early childhood education in Nigeria: A reality or a mirage? ContemporaryIssues in Early Childhood, 9(4). http://doi: 10.2304/ciec.2008.9.4.375.

Akyeampong, K. (2017). Teacher educators' practice and vision of good teaching in teacher education reform context in Ghana. Educational Researcher, 46(4), 194-203. https://doi.org/10.3102/0013189X17711907.

Aizenman, N., \& Warner, G. (2018, June 19). What we can learn from Ghana's obsession with preschool [Radio Broadcast]. National Public Radio. Retrieved https://www.npr.org/sections/goatsandsoda/2018/06/19/613655788/when-it-comes-to-preschool-does-fatherreally-know-best. October 102018.

Arseven, A. (2014). The Reggio Emilia approach and curriculum development process. International Journal of Academic Research Part B, 6(1), 166-171. doi: 10.7813/2075-4124.2014/6-1/B.23.

Asare, K. (2015). Exploring the kindergarten teachers' assessment practices in Ghana. Developing Country Studies, 5(8), 110-128.

Asare, K.B. \& Nti, S. K. (2014). Teacher education in Ghana: A contemporary synopsis and Matters Arising. Retrieved

from https://www.researchgate.net/publication/289815964_Teacher_Education_in_Ghana_A_Contemporary_Sy nopsis and Matters Arising. April 29, 2020.

Aoki, T. T. (1993). The child-centered curriculum: Where is the social in pedocentricism?In W. F. Pinar \& R. L. Irwin

(Eds.), Curriculum in a new key: The collected works of Ted T. Aoki (pp. 279-289). Mahwah, NJ: Lawrence Erlbaum.

Bartman, A. (2002). Spare the rod and spoil the child corporal punishment in schools around the world. Indiana International \& Comparative Law Review, 13(1), 283-316.

Ball, J. (2010). Culture and early childhood education. Encyclopedia on early childhood development. Retrieved from; http:/www.child encyclopedia.com/culture/accordingexperts/culture-and-early-childhood-education November 27, 2018.

Bell, R.H. (2002). Understanding African philosophy: A cross-cultural approach to classical and contemporary issues. London: Routledge.

Bidwell, K., \& Watine, L. (2014). Exploring early education programs in peri-urban settings in Africa: Final report.

Innovations for Poverty Action, New Haven, CT. Retrieved from http://www. povertyaction.org/sites/default/files/publications/final_ecd_report_full.pdf. May 14th 2020. 
Boakye-Boateng, A. (2010).Changes in the concept of childhood: Implications on children in Ghana. The Journal of International Social Research, 3(10), 104-115.

Boakye, J. K. A., Etse, S., Adamu-Issah, M., Moti, M. D., Matjila, J. L., \& Shikwambi, S. J. (2008). ECD Policy: A Comparative Analysis in Ghana, Mauritius, and Namibia. In M. A. Garcia, A. Pence \& J. L. Evans. (Eds.). Africa's Future, Africa's Challenge Early Childhood Care and Development in Sub-Saharan Africa (pp.169185). The International Bank for Reconstruction and Development / The World Bank. Washington DC.

Boateng, F. (1983). African traditional education: A method of disseminating cultural values. Journal of Black Studies, 13(3), 321-336.

Bronfenbrenner, U. (1979). The ecology of human development. Cambridge, MA: Harvard University Press.

Bruner, J. (1960). The process of education. Harvard University Press.

Bruner, J. (1971). The process of education revisited. The Phi Delta Kappan, 53(1), 18-21.

Calderon, D. (2014). Speaking back to manifest destinies: A land education-based approach to critical curriculum inquiry. Environmental Education Research, 20(1), 24-36. DOI: 10.1080/13504622.2013.865114.

Casely-Hayford, L., Palmer, R. Ayamdoo, C., \& Thompson, N.M. (2007). Aid and donor partnerships' in Ghana's education sector, 1987-2007: A critical review of the literature and progress. Retrieved from http://citeseerx.ist.psu.edu/viewdoc/download?doi=10.1.1.521.1426\&rep=rep1\&type=pd. August 29, 2019.

Cobbold, C., \& Boateng, P. (2015). Exploring the instructional practices efficacy beliefs of kindergarten teachers in the Kumasi Metropolis of Ghana. Journal of Education Development and Practice, 5(6), 173-187.

Creider, C. A. (1977). Towards a description of east African gestures. Sign Language Studies, (14) 1-20.

Dahlberg, G., \& Moss, P. (2005). Ethics and politics in early childhood education. New York, NY: Routledge Falmer.

Dei, G. J. S. (2000). Rethinking the role of Indigenous knowledges in the academy, International Journal of Inclusive Education, 4(2), 111-132. doi:10.1080/136031100284849

Dewey, J. (1938). Experiential education. Chicago: University of Chicago Press.

Donkor, A.K., Issaka, C. A., \& Asante, J. (2013). Cultural practices and education in Ghana: The effects of traditional culture on parental involvement in education. Research on Humanities and Social Sciences, 3(7).

Edwards, C., Gandini, L., \& Forman, G. (1993). The hundred languages of children: The Reggio Emilia approach to early child- hood education. Norwood, NJ: Ablex.

Fafunwa, B. (1991). History of education in Nigeria. Ibadan: NPS. Pub.

Fakudze, C., \& Rollnick, M. (2008). Language, culture, ontological assumptions, epistemological beliefs, and knowledge about nature and naturally occurring events: Southern African perspective. L1 - Educational Studies in Language and Literature, 8(1), 69-94. DOI: 10.17239/L1ESLL-2008.08.01.05.

Freire, P. (1972). Pedagogy of the Oppressed. Harmondsworth: Penguin.

Fung, C.K.H. (2015). "Active child" and "active teacher": Complementary roles in sustaining child-centered curriculum, childhood education, 91(6), 420-431, DOI: 10.1080/00094056.2015.1114787

Garcia, M., Pence, A., \& Evans J. L. (Eds.). (2008). Africa's future, Africa's challenge early childhood care anddDevelopment in Sub-Saharan Africa. The International Bank for Reconstruction and Development / The World Bank.

Gyekye, K.(1997). Tradition and modernity: Philosophical reflections on the African experience. New York: Oxford University Press.

Hansungule, M. (2005). Administering the African society through the law. In S. L.S-M. Linholt (Ed.). Human Rights in Development: Human Rights and Local/ Living Law (pp. 371-401). Leiden/Boston: Martinus Nijohoff.

Hewett, V. M. (2001). Examining the Reggio Emilia Approach to Early Childhood Education. Early Childhood Education Journal, 29(2), 95-100.

Hyde, K. A. L., \& Kabiru, M.N. (2003). Early childhood development as an important strategy to improve learning outcomes. Working Group on Early Childhood Development. Association for the Development of Education in Africa, Quality Study.

Idang, G. E. (2015). African culture and values. Unisa Press, 16 (2), 97-111.

Jegede, O. (1994). African cultural perspective and the teaching of science. In J. Solomon \& G. Aikenhead (Eds.). STS education: International perspectives on reform (pp. 120-130). New York: Teachers College Press.

Jaramillo, A., \& Tietjen, K. (2001). Early childhood development in Africa: Can we do more for less? World Bank. Washington, D.C.

Kabay, S., Wolf, S., \& Yoshikawa, H. (2017). "So that his mind will open": Parental perceptions of preschool in urbanizing Ghana. International Journal of Educational Development, 57, 44-53. https://doi.org/10.1016/j.ijedudev.2017.08.013.

Khupe, C. (2014). Indigenous knowledge and school science: Possibilities for integration (Doctoral dissertation). University of the Witwatersrand, South Africa. Retrieved from http://mobile.wiredspace.wits.ac.za/bitstream/handle/10539/15109/C.\%20Khupe\%20Thesis.pdf?sequence= 
2. May 31, 2020.

Kilbride, P. L., \& Kilbride, J.C. (1990). Changing family life in east Africa: Women and children at risk. Penn State University Press.

Lillard, A. S. (2017). Montessori: The science behind the genius. Third edition. Oxford University Press. USA

MacBeath, J. (2010). Living with the colonial legacy; The Ghana story. The Center for Commonwealth Education Report No $\quad 3 . \quad$ Retrieved

https://www.educ.cam.ac.uk/centres/archive/cce/publications/CCE_Report_No3-

Ghana_LivingTheColonialLegacy.pdf. June $20^{\text {th }} 2019$.

McCoy, D.C., \& Wolf, S. (2018). Changes in classroom quality predict Ghanaian preschoolers' gains in academic and social-emotional skills. Developmental Psychology, 54(8), 1582-1599. DOI: http://dx.doi.org/10.1037/dev0000546.

McCoy, D. C., Peet, E. D., Ezzati, M., Danaei, G., Black, M. M., Sudfeld, C. R., \& Fink, G. (2016). Early childhood developmental status in low-and middle-income countries: National, regional, and global prevalence estimates using predictive modeling. PLoS Med, 13, e1002034, http://dx.doi.org/10.1371/journal.pmed.1002034

McWillian, H.O.A., \& Kwamena-Poh, M.A. (1975). The development of education in Ghana. London: Longman

Ministry of Women and Children's Affairs, Ghana, (2004). Early childhood care and development policy. Retrieved from https://planipolis.iiep.unesco.org/sites/planipolis/files/ressources/ghanaeccdp.pdf. September $10,2019$.

Ministry of Education (2019). Kindergarten Curriculum (KG 1\&2). Retrieved from; file:///C:/Users/John\%20Bosco/Desktop/BACKUP/TD1/KG-Curriculum.pdf. February $2^{\text {nd }} 2020$.

Ministry of Education. (2018). Education Sector Analysis 2018. Retrieved from; https://www.globalpartnership.org/sites/default/files/2019-05-ghana-education-sector-analysis.pdf. April 26, 2020

Ministry of Education. (2016). Ghana 2016 National Education Assessment Report of Findings. Retrieved from; https://globalreadingnetwork.net/sites/default/files/eddata/2016\%20NEA\%20Findings\%20Report_17Nov20 16_Public\%20FINAL.PDF. April 26, 2020

Ministry of Education. (2006). Curriculum for kindergarten (Kindergarten 1-2), Curriculum Research and Development Division, Ghana Education Service, Accra, Ghana

Morrison, J.W. (2012).Early care and education in Ghana. Childhood Education International, 77(4), 214-218.

Mundy-Castle, A. C. (1974). Social and technological intelligence in Western and non-Western cultures. Universita (University of Ghana), 4, 46

Muyila, J.W. (2006). African values and the problem of the rights of the child: A search for explanations. In: AK Tonnesen (Ed.): Research Partnership 3/ 2006. Copenhagen: The Danish Institute for Human Rights, pp. 153.

Ndofirepi, A. P., \& Shumba, A. (2014). Conceptions of "Child" among Traditional Africans: A Philosophical Purview. Journal of Human Ecology, 45(3)233-242. https://doi.org/10.1080/09709274.2014.11906696.

Ndofirepi, A.P. (2011). Philosophy for Children: the quest for an African perspective. South African Journal of Education.31, 246-256. DOI: 10.4314/saje.v31i2.66458.

Ng'asike, J. T. (2014). African early childhood development curriculum and pedagogy for Turkana nomadic pastoralist communities of Kenya. New Directions for Child and Adolescent Development, (146), 43-60. doi:10.1002/cad.20072.

Nsamenang, A. B. (2005).The intersection of traditional African education with school learning. In Swatz, Leslie, de la Ray Cheryl \& D. Noman (Eds.), (2005). Psychology : An introduction (pp.327-337). Cape Town South Africa. Oxford University Press.

Nsamenang, A. B. (2007). A critical peek at early childhood care and education in Africa. Child Health and Education, 1(1), 14-26. doi=10.1.1.586.7464.

Nsamenang, A. B. (2008). (Mis) Understanding ECD in Africa: The force of local and global motives. In M. Garcia, A. Pence \& Evans J. L. (Eds.). Africa's Future, Africa's Challenge Early Childhood Care and Development in Sub-Saharan Africa (pp.135-146). The International Bank for Reconstruction and Development / The World Bank . Washington DC.

Nsamenang, A. B., \& Tchombe T.M.S.(2011). Handbook of African educational theories and practices A Generative Teacher Education Curriculum Presses. Human Development Resource Centre (HDRC). Bamenda, North West Region Cameroon.

Ntuli, C.D. (2012). Intercultural misunderstanding in South Africa: An analysis of nonverbal communication behaviour in context. Intercultural Communication Studies, XXI, 2

Ogbujah, C. (2013).Impacts of Dewey's educational ideas on Nigeria's educational system. Rivers State University Of Science \& Technology, Port Harcourt. Retrieved from; file:///C:/Users/Gale/Downloads/ImpactsofDeweyseducationalideas-Autosaved-\%20(1).pdf. August 13, 
2019.

Okai, M., \& Amoah, A. K.(2016). How far with Ghana's early childhood care and development ?. Retrieved from; https://www.modernghana.com/news/715064/how-far-with-ghanas-early-childhood-care-anddevelopment.html. September 14, 2018.

Olaleye, O. O., \& Omotayo, K. A. (2009). Assessment of quality in early childhood education in Ekiti-State Nigeria. World Applied Sciences Journal. 7(5), 683688. Retrieved from http://www.idosi.org/wasj/wasj7(5)/19.pdf. April 22, 2020

Onu, V. C., Obiozor, W. E., Agbo, O. E., \& Chiamaka, E. (2010). Integration and innovation in early childhood education in Nigeria: Implications for quality teacher production. African Journal of Teacher Education, 1(1), 209-221.

Onwauchi, P. C. (1972). African peoples and western education. The Journal of Negro Education, 41(3), 241-247. DOI: $10.2307 / 2966999$.

Osei-Poku, P., \& Gyekye-Ampofo, M. (2017). Curriculum delivery in early childhood education: Evidence from selected public kindergartens in Ashanti region, Ghana. British Journal of Education, 5(5), 72-82.

Owuor, J. A. (2007). Integrating African Indigenous knowledge in Kenya's formal education system: The potential for sustainable development. Journal of Contemporary Issues in Education, 2(2), 21-37. https://doi.org/10.20355/C5Z594.

Owu-Ewie, C. (2006). The language policy of education in Ghana: A critical look at the English-Only language policy of education. Ohio University, Athens, Ohio. Retrieved fromhttp://www.lingref.com/cpp/acal/35/paper1298.pdf. July $17^{\text {th }} 2019$.

Pence, A.R., \& Nsamenang, A. B. (2008). A case for early childhood development in sub-Saharan Africa. The Hague: Bernard van Leer Foundation.

Pence, A., \& Shafer, J. (2006). Indigenous knowledge and early childhood development in Africa: The early childhood development virtual University. Journal for Education in International Development, 2(3).

Pence, A. R., \& Marfo, K. (2008). Early childhood development in Africa: Interrogating constraints of prevailing knowledge bases. International Journal of Psychology, 2, 78-87. https://doi: 10.1080/00207590701859143

Piaget, J. (1936). Origins of intelligence in the child. London: Routledge \& Kegan Paul.

Prochner, L., \& Kabiru, M. (2008). ECD in Africa: A historical perspective. In M. Garcia, A. Pence \& Evans J. L.

(Eds.). (2008). Africa's Future, Africa's Challenge Early Childhood Care and Development in Sub-Saharan Africa (pp.117-130). The International Bank for Reconstruction and Development / The World Bank . Washington DC.

Rwezaura, B. (1998). Competing 'images' of childhood in the social and legal systems of contemporary subSaharan Africa. International Journal of Law, Policy and the Family, 12, 253-278. https://doi.org/10.1093/lawfam/12.3.253

Saayman, W. (1991). 'Who owns the schools will own Africa' Christian mission, education and culture in Africa. Journal for the Study of Religion, 4(2), 29-44.

Samuelsson, P. I., \& Kaga, Y. (2008). The contribution of early childhood education to a sustainable society. United Nations Education, Scientific, and Cultural Organization.

Serpell, R. (1994). An African social ontogeny: Review of A. Bame Nsamenang (1992), Human development in cultural context. Cross-Cultural Psychology Bulletin, 28(1), 17-21.

Shizha, E. (2007). "Critical analysis of problems encountered in incorporating Indigenous Knowledge in science teaching by primary school teachers in Zimbabwe". Youth and Children's Studies, 53(3), 302-319.

Sofo, S. Asola, E. F. \& Ocansey, R. (2019). An assessment of Ghana's enacted kindergarten curriculum. African Journal of Teacher Education. 8, 86-110. http://doi: 10.21083/ajote.v8i0.5174.

Stephen, C. (2012). Looking for theory in preschool education. Studies in the Philosophy of Education, 31, 221238. http://doi: 10.1007/s11217-012-9288-5.

Straus, M., \& Paschall, M. (1998). Corporal punishment by mothers and child's cognitive development: A longitudinal study. Family Research Laboratory, University of New Hampshire: Durham, New Hampshire.

Tackie-Ofosu, V., Mahama, S., Vandyck, E. S. T. D., Kumador, D. K., \& Toku, N. A. A. (2015). Mother tongue usage in Ghanaian pre-schools: Perceptions of parents and teachers. Journal of Education and Practice. 6(34), 81-87.

Taiwo, O. (1976). Culture and the Nigerian novel. New York: St Martins Press.

Tedla, E. (1995). Sankofa: African thoughts and education. New York, NY: Peter Lang

Tzuo, P. W. (2007). The Tension between Teacher Control and Children's Freedom in a Child-centered Classroom: Resolving the Practical Dilemma through a Closer Look at the Related Theories. Early Childhood Education Journal, 35(1). http://doi: 10.1007/s10643-007-0166-7

United Nations Educational, Scientific and Cultural Organization [UNESCO] International Bureau of Education (IBE).(2006). Country profile prepared for the Education for All Global Monitoring Report 2007 Strong Foundations: Early Childhood Care and Education Ghana Early Childhood Care and Education (ECCE) 
programmes. Retrieved from; http://unesdoc.unesco.org/images/0014/001471/147192e.pdf. September 21, 2018

United Nations Educational, Scientific and Cultural Organization [UNESCO]. (2006). EFA global monitoring report 2007: Strong foundations: Early childhood care and education, UNESCO.

Vygotsky, L. S. (1978). Mind in society: The development of higher psychological processes. Cambridge, MA: Harvard University Press.

Vygotsky, L.S. (1986). Thought and language (A. Kozulin, Trans.). Cambridge, MA: MIT Press.

Weikart, D. P. (1971). Relationship of Curriculum, Teaching, and Learning in Preschool Education. 35p.; Paper presented at the Hyman Blumberg Memorial Symposium on Research in Early Childhood Educaticn, Baltimcre, Maryland, February, 1971. Retrieved from; https:/files.eric.ed.gov/fulltext/ED049837.pdf. April 21,2020

Weisner, T. S. (1997). Support for children and the African family crises. In T.S. Weisner,C. Bradley \&C.P. Kilbride (Eds.). African families and the crises of social change (pp.20-40). Westport. CT: Bergin \& Garvey.

Wexler, A. (2004). A theory for living: Walking with Reggio Emilia. Art Education, 57(6), 13-19. https://doi.org/10.1080/00043125.2004.11653571

Wieschhoff, H. A. (1938).Concepts of right and left in African cultures. Journal of the American Oriental Society, 58 (1), 202-217.

Woodhouse, H., \& Ndongko, T. (1993). Women and science education in Cameroon: Some critical reflections. Interchange, 24(1 \& 2), 131-158 